\title{
Kafkaslarda Rus Yayılması Karşısında Osmanlı-Kaçar Faktörünün Harekete Geçirilme Teşebbüsü (Ağustos-Eylül 1811) \\ Hasan Oktay*
}

\section{Özet}

Türk-Rus savaşları ve rekabeti zor devrelerden geçmiştir. Kafkaslar üzerinde verilen hakimiyet mücadelesi Rusya'yı imparatorluk serüveninde iyi bir yere taşırken Türklere ise Osmanlı ve Kaçar imparatorluğunu yaklaşık yüzyıl sonra kaybettirmiştir, Aynı zamanda geniş bir Türk coğrafyası da Rus işgaline uğramıştır. Kafkasya Türk Rus mücadelesinin en kritik noktasıdır. Burayı elinde tutan imparatorluğunu pekiştirir tutamayan ise imparatorluğunu kaybeder. Rus Türk mücadelesinde Türkler iki ana unsura (Şii-Sünni)ayrılıp kendi aralarında rekabete kalkışınca ibre Ruslara doğru kaymaya başladı. İşte bu noktada tarihi dönüm noktası ve altın vuruş fırsatı doğdu tarih Türklere yeşil ışık yaktı ve (Ağustos-Eylül 1811) tarihinde bir ittifak umudu doğmuştu. İran coğrafyasında Safevi sonrası varlığını devamlılığını sürdürebilen Türk devleti kaçar hanedanı ile i̇stanbul merkezli Osmanlı Türk imparatorluğu Kafkaslarda gelişen Rus yayılması karşısında belki de ilk defa birlikte hareket etme fırsatı buldular. Bu fırsatı değerlendirmek için büyük gayret sarf ettiler. Emin Paşa'ya Ruslar tarafından tertip ettirilen suikast bir millete iki imparatorluk kaybettirdi. Ruslara ise imparatorluklarını pekiştirme fırsatı verdi. Kafkasya'daki hakimiyet mücadelesi hala devam etmektedir. Bu makalede Rus istilası karşısında fırsata dönüşebilecek bir ittifaka dikkat çekilmeye çalışıldı.

Anahtar Kelimeler: Türk, Rus, İmparatorluk, İran, Osmanlı, İstanbul, Kafkaslar

The enacting attempt of the Ottoman-Qajar Factor against the Russian expansion in the Caucasus (August-September 1811)

\section{Abstract}

The Russo-Turkish wars and rivalry passed very interesting periods. While the struggle over the dominance of Caucasus brought advantage to Russian Empire, it caused Turks to lose the Ottoman Empire. Simultaneously, a broad Turkic geopolitical area was occupied by Russia. Caucasus is the most critic point of the Russo-Turk struggle. The empire which holds this area

* Doç. Dr., Uluslararası Vizyon Üniversitesi Rektör Yardımcısı, KAFKASSAM Başkanı, hasanoktay2002@yahoo.com. (ORCID ID: 0000-0002-2372-0655)

(Makale Gönderim Tarihi: 11.08.2017, Makale Kabul Tarihi: 03.11.2017)

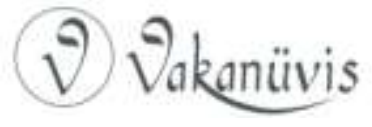


consolidates itself and that who failed to do it loses itself. As soon as Turks were separated to two elements and oppose each other during the RussoTurk rivalry, situation began to be advantageous for Russia. This situation was historic turning point for Turks. Qajar Dynasty, which is a Turkic state established after Safavid Dynasty and Ottoman-Turkish Empire whose center was Istanbul found the chance to act together for the first time against Russia consolidating its dominance in Caucasus. They made great efforts to benefit this chance. The assassination of Emin Pasha realized by Russians led Turks lose two their empires and gave a chance to consolidate their empire to Russians. The struggle over the dominance of Caucasus still continues.

Keywords: Russians, Turks, Iran, the Ottoman Empire, Caucasus

\section{Giriş}

Vistül nehri, Pripet havzasıyla orta Dinyeper sahasında ortaya çıkan Slavlar 1 Türk ve Germenlerin baskısıyla çevreye yayılmaya başlamışlardır ki, bu yayılma kavimler göçüyle birlikte daha da hızlanmıştır. Bundan sonra Avar, Hazar ${ }^{2}$, Bulgar vs gibi hakim

\footnotetext{
1 Bugünkü Rusya topraklarında Taş Devri'nden bu yana bir dizi uygarlık yaşamıştır. Tarihi kaynaklar, M.Ö. VII. yy ile M.S. IX. yy arasında Kimmerler, İskitler, Sarmatlar, Antlar ve başka halkların buralarda yerleşik olduklarını ortaya koyuyor. Rusların kökleri Slav ailesine dayanır. Bu aile, Doğu Slavları (Ruslar, Ukraynalılar, Belaruslar), Batı Slavları (Polonyalılar, Çekler, Slovaklar vs.) ve Güney Slavları (Bulgarlar, Sırplar, Hırvatlar, Slovenler, Makedonyalılar vs.) olarak kendi arasında üçe ayrılır. Bunlar dilleri bakımından Hind-Avrupa halklarıdır. İlk Slav vatanının, Vistül Nehri ile Pripet Havzası ve Orta Dnepr arasında olduğu sanılıyor. Hunlar ve Gotlar döneminde var olan Slav kavimleri VI. yy'da Avarların istilasına hedef oldular. Ardından Hazarların egemenliği gündeme geldi.

Doğu Slavları Dnepr, Volga, Don nehirleri civarındaki ormanlık alanda yaşıyorlardı. Zamanla Fin kavimlerinin topraklarına doğru ilerlemeye başladılar. Doğu Slavları ile İsveçlilerin ataları sayılan Normanlar arasında uzun çatışma dönemleri yaşandı.

"Rus" adının kökeni genellikle Norman Okulu ile bağı sayılır. "Rus" veya "Rusi" kelimesinin, muhtemelen Fincedeki "Ruotsi"den geldiği kabul edilir. Bu, Naeller Gölü (Stockholm civarında) yakınlarındaki isveçlililere takılan addı. Bunun "kayıkçılar, kürekçiler" anlamına geldiği söylenegelir. Kelime Slavcaya önce "Rusi" sonra da "Rus" olarak geçmiştir.

Şaban Kuzgun, Hazar ve Karay Türkleri, Ankara 1993, s. 87 vd.
}

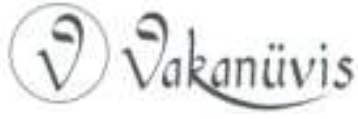


unsurların etkisinde yaşayan Slav kavimlerin alt tabakalarından birini oluşturan Rusların teşekkül ettiği görülmektedir. ${ }^{3}$

Yaklaşık iki yüz elli yıl Altınordu devletinin hâkimiyetinde kalan Rusların ${ }^{4}$, bu devletin Timur tarafından yıkılmasından istifade ederek 1302 yılından beri ön plana çıkarmaya çalıştıkları Moskova Kınezliği etrafında birleştiği görülmektedir 5 .

17. yy. da Romonof hanedanının iktidara gelmesiyle Rusya hızla gelişmeye başladı. Bu hanedanın en başarılı ismi Deli Petro (16871725) yönetiminde bir yandan askeri alanda batılılaşmasını tamamlayan Rusya, aynı zamanda gelecekteki Rus yayılmasının ana hedeflerini de belirlemiş6; Petro dönemi Rusya bir yandan Akdeniz'e öte yandan Hindistan'a ulaşacak bir programı uygulamaya koymuştu. Türkistan ve Hindistan'ı ele geçirmenin yolu Osmanlı Devletinin bu bölge ile irtibatının kesilmesiyle olacağını bilen Ruslar Kafkaslara doğru bir harekat ile yayılmaya başlamışlardı 7 .

16. yy.dan sonra Avrupa'da başlayan sömürgecilik hareketi neticesi ipek ve baharatın kaynağı Hindistan önemli bir merkez haline geldi 8 . Ruslar Kazan Hanlığını ortadan kaldırdıktan sonra Kafkasya ve Türkistan için tehdit oluşturmaya başladı. 9 Özellikle Küçük Kaynarca

\footnotetext{
3 Akdes Nimet Kurat, Türkiye ve Rusya, Ankara 1990, s. 1-5; Ilyas Kamalov, Altınorda ve Rusya, İstanbul 2009, s. 59-60;

4 George Vernadsky, Moğollar ve Ruslar, İstanbul 2007; Altay Tayfun Özcan, Moğol Rus ilişkileri, Ankara 2017.

5 Mustafa Kafalı, Altın Orda Hanlıklarının Kuruluş ve Yükseliş Devirleri, İstanbul 1980; Yakubovsky, Altınordu ve Çöküşü, Ankara 1976, 41 vd.

'Daha geniş bilgi için bkz, "I. Petro'nun 1725 yılında yazdığı vasiyetnamesi", Türk Kültürü Dergisi, Ankara 1990, XXVIII/323 s.160-163; Kurat, a.g.e., s. 11.

7 J. F. Baddeley, Rusların Kafkasyayı İstilası ve Şeyh Şamil, İstanbul 1989, s. 20.

Hindistan'ı elinde bulundurmak dünya siyasetine yön vermek süper devlet olmak o yüzyılın en önemli anlayışlarındandı. Orhan Yazıcı, Afganistan'da ingiliz-Rus Nüfuz Mücadelesi, Malatya 1996, basılmamış yüksek lisans tezi.

9 Akdes Nimet Kurat Türkiye ve idil Boyu, Ankara 2011, s. 60; Sekan Acar, "Kazan Hanlığı", Avrasyanın Sekiz Asrı Çengizoğulları, İstanbul 2016, s. 248-284.
}

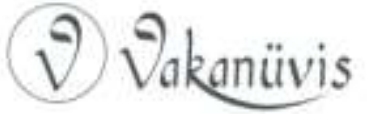


Anlaşmasından sonra bölge için Rus tehditleri hızla artmaktaydı10. Ruslar gelişen sömürgecilik hareketinden pay alabilmek, sıcak denizlere inebilmek için önünde büyük bir engel teşkil eden Kafkas dağlarını aşarak Basra Körfezine inmek istiyordu. Ruslar için hedef alanındaki Müslüman nüfus üzerinde Osmanlı Devletinin tesirini kırabilmek, dolayısıyla kara irtibatının kesilmesi gerekiyordu. Osmanlı İran rekabeti başta Türkistan coğrafyası olmak üzere Kafkaslar bir coğrafi kavram olarak ele alındığında doğu İslam alemini zayıflatmış Basra körfezi Kafkas dağları arasındaki hat doğu-batı İslam dünyası arasında ince ve kırılgan bir bölge olarak stratejik önem kazanmıştı ${ }^{11}$. Bu bölgeyi kontrol etmek Ruslar için her geçen gün çok daha önemli hale geliyordu. Ruslar bu niyetlerini uygulamaya çalışırken İran coğrafyasında hakimiyetini sürdüren ve Osmanlı devleti ile Şah İsmail'den beri ciddi bir rekabete giren önce Afşarlar sonra da Kaçar Türk hanedanlarının yönetimi devam ediyordu. Afşar hanedanından Nadir şahın 1747de bir suikast ile ölümüyle İran coğrafyası geçici bir yönetim krizine girmiş, Tebriz ve civarı başta olmak üzere kuzeye, Kafkas sıra dağlarına doğru yirmiye yakın merkezi otoriteden uzak hanlık kuruldu12.

10

Osmanlı İmparatorluğunun hinterlandı sayılan Türkistan aynı zamanda Ruslar için Hindistan'a gidiş yolu üzerinde önemli bir merkezdir. Osman Köse, 1774 Küçükkaynarca Anlaşması, TTK Ankara 2006; Akdes Nimet Kurat, Türkiye ve Rusya, s.24vd.

11

Ensar Köse, XVIII. Yüzyılın Başlarında Kafkaslarda Nüfuz Mücadelesi, yayınlanmamış yüksek lisans tezi, İstanbul 1996. Tarihi coğrafyada böyle bir ayrım söz konusu değildir. Fakat tarihi etkileyen dönüm noktalarından sayılabilecek bu mücadele alanı Türkistan Türkleri ile Anadolu Türkleri arasında bir kesişme birleşme sınırı olarak ifade edilmektedir.

12 Azerbaycan hanlıkları için bakınız, Bakıhanov, Gülistan-ı Irem, Bakü 1941, Abdullaev, G.B, Azerbaidzhana v XVIII Veke I Vzaimaotnoshcnira s Roussie, Bakü 1965; Azerbaycan Tarihi, Azerbaycan ilimler Akademisi Yayınları, Bakü 1964; Azerbaycan Tarihi, en eski devirlerden XX. asrın evveline kadar, Azerbaycan ilimler Akademisi yayınları, Bakü 1992; Hasan Ali Delili, XVIII. Asrın Ikinci Yarısında Cenubi Azerbaycan Hanlıkları, Bakü 1979. Hanlıklar hakkında üniversitelerimizde tezler yapılmaya başlanmıştır, Emre Nusel, 1787-1792 Osmanlı-Rus Savaşında Kafkas Hanlıklarının Faaliyetleri, yayınlanmamış yüksek lisans tezi, Edirne 2015.

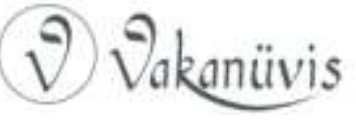




\section{Hanlıklar Kafkasyası}

Rusya, Osmanlı, İran Kaçar hanedanı arasında sıkışıp kalan Güney Kafkasya güç mücadelelerinin odağı haline gelirken bu üç devlete nazaran oldukça zayıf nitelikteki hanlıkların ortaya çıkması bölgede rekabeti hakimiyet mücadelesini kızıştırıyordu. 13

Bölgede kurulan hanlıkların aynı zamanda birbirleriyle mücadele içerisinde olması Rusların Kafkasya üzerinden emellerini gerçekleştirmesi için iyi bir fırsat olmuş oldu. Hanlıklar modern devlet sürecinin şartlarını yakalama fırsatı elde edememiş, şehir devletçileri gibi kısır bir döngüye düşmüşlerdi. Bununla birlikte hanlıklar arasında dikkat çeken Revan hanlığı bölgedeki gelişmeleri diğer hanlıklara göre daha iyi takip edebiliyor Osmanlı ve Kaçar hanedanı ile yakın ilişki kurarak yaklaşmakta olan tehlikeyi görmüş ve Rus yayılmasının önüne geçmeye çalışıyordu14. Rus yayılması karşısında 80 yıl kadar varlık mücadelesini sürdürebilen Revan hanlığının önemli hanlarından biri olan Hüseyin Han, Rus saldırılarından oldukça zarar gördüğü gibi neticede meydana gelebilecek durumun da farkındaydı. ${ }^{15}$ Onun için iki Türk ve Müslüman ülke olan İran/Kaçar ile Osmanlı Devletinin Ruslara karşı birleşmeleri hem bölge açısından hem de bu iki ülkenin geleceği açısından çok önemliydi. Revan Hanı bu durumu görmüş ve bir an önce bölgesel bir ittifakın kurulması gerektiğine inanıyordu. Fakat her iki devletin aralarındaki tarihi çekişme bu tehlikeyi görmelerini engelliyordu.

Revan hanı Hüseyin Han ${ }^{16}$, Osmanlı Devletinin Şark seraskeri Hacı İbrahim Paşaya 1810 yılının Mayıs ayında gönderdiği bir mektupta, bu vahim konu izah edildikten sonra muhakkak Ruslara karşı birlik olunması gerektiğini ifade ediyordu. Bu ittifakın Ahıska yakınlarına

\footnotetext{
${ }^{13}$ Mustafa Aydın, Üç Büyük Gücün Çatışma Alanı Kafkaslar, İstanbul 2008.

Revan Hanlığı için bakınız, Hasan Oktay, Revan Hanlığı, Malatya 1997, (yayınlanmamış doktora tezi)

${ }^{15}$ Hasan Oktay, "Osmanlı -Rus-ïran Rekabetinde Revan Hanlığı ve Hanları", VIII. Milletlerarası Türkoloji Kongresi, IV, s. 978, İstanbul 2014.

${ }^{16}$ Hasan Oktay, "Revan Hanlığı ve Hanları”, Tarihte Türkler ve Ermeniler, IV, s. 166, TTK yayınları Ankara 2014; Oktay, a.g.m., s. 978.
}

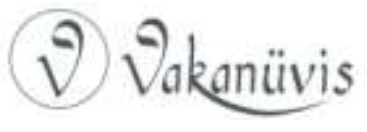


kadar gelen Rus ordusunun meydana getirdiği tehlike göz önünde bulundurularak derhal olmasını istiyordu 17 . Kaçar orduları başkomutanı Abbas Mirza'da İstanbul'a sık sık mektuplar yazarak bu ittifakın bir an önce tesisini rica ediyordu. 16 Temmuz 1810 tarihli bir name ile Şark seraskerine Kaçarlara kurşun verilmesi ve ne gerekirse

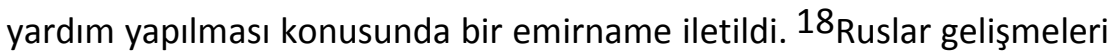
gün gün takip ederek bir Osmanlı İran ittifakının gerçekleşmesi halinde bölgede tutunamayacaklarını bildiklerinden olsa gerek Rus general Tormosof İran ile müzakere görüşmeleri yapmak üzere Tebriz'e Abbas Mirzanın yanına Baron Vredei başkanlığında bir elçilik heyeti gönderdi.19

Doğu sınırlarındaki hareketliliği yakından takip eden Osmanlı devleti ise doğu cephesinde harekete geçilmesi için şark seraskerine gerekli yardımın yapılmasına karar verdi ${ }^{20}$. Ruslar Tiflis'e girdikten sonra Açıkbaş vilayeti hakimi ve Osmanlı İmparatorluğu ile yakın mesai içerisinde olan Solomon'u sıkıştırmaya başlamışlar ve Solomon'da bu baskılara dayanamayarak Ahıska'ya kaçmıştı ${ }^{21}$.

Kaçar devleti İngilizlerinde araya girmeleriyle Osmanlı devletine 21 Temmuz'da uzun bir mektup göndererek Rusya'ya karşı bir ittifak kurma yolunda büyük bir mesafe kat etti22. Sultan II. Mahmut İran'dan gelen bu mektup karşısında derhal harekete geçilmesinin

\footnotetext{
${ }^{17} B O A$, HH., nr.,36676; Bu ittifak teklifi için bkz. BOA., Cevdet Hariciye, (C.H), nr. 2623.

18 BOA, HH., $\mathrm{nr} 36857 \mathrm{~A}$

Yahya Kalantari, a.g.e., s, 66-67.

${ }^{20} B O A, H H, 36696 ;$ Bu mektubun İstanbul'a İngiliz elçiliği vasıtasıyla ulaşması Rus tehlikesine karşı Osmanlı Kaçar ittifakını oluşturma niyetinin İngilizlere ait olduğunu söylemek mümkündür. Zira İngilizler Ruslar ile Hindistan'da girişecekleri rekabeti önlemek için Rusya'ya karşı bir ittifak arayışı içerisindedir. Ruslar Kafkaslarda durdurulursa İngilizler Hindistan'da rahatça hareket edebileceklerdir.

${ }^{21}$ Ahmed Cevdet Paşa, Tarihi Cevdet, V, 2400; Solomonun faaliyetleri için bkz, Mehman Süleymanov, Gülistan Müqavilesi, I-II, Bakü 2014. Henry J Armani, The Russian Annexation of Imeratıa (1800-1815), Washington 1970, s. 370.

BOA, $\mathrm{HH}, 36986$.
}

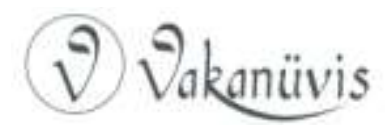


buyurdu 23 . Nihayet İttifakın şekli Ağustos 1810 da yavaş yavaş ortaya çıkmaya başladı.

Hüseyin Han yedi bin kişilik bir orduyla Ahıska Paşası Şerif Paşa'nın yardımına koştu. Bu bölgeler Osmanlı Devletine bağlı olmasına rağmen Osmanlı Şark seraskeri pek gevşek davranıyordu. Osmanlının doğu eyaletlerindeki Paşaları kendi aralarındaki çekişmeyi bir kenara bırakarak yaklaşan tehlikeye karşı önlem alma konusunda bir birliktelik sağlayamıyorlardı24. Kaçar hanedanı üyesi olan ve Rus meselesini daha ilk başından beri kavrayıp ona göre tedbir alınması konusunda son derece hassas olan Abbas Mirza İstanbul'a aynı muhtevada bir mektup gönderince 25 Bab-ı Ali Şark cephesinde harekete geçmesi için Seraskere emir verdi 26 . Ayrıca Revan Hanlığına doksan altı deveden oluşan bir kervanla çeşitli savaş malzemesi gönderildi27. Revan Hanı Hüseyin Han'ın ve Kaçar orduları komutanı Abbas Mirza'nın bu temasları netice vermeye başladı ve nihayet Hüseyin Han ile Ahıska Paşası Şerif Paşa buluşup Gürcistan'a saldıracaklardı28.

Rus orduları komutanı General Tormosov bu ittifak görüşmelerinden casusları vasıtasıyla haber alınca General Pauollotch'i ittifakın etkisini azaltabilmek için görevlendirdi. ${ }^{29}$ General iyi yetişmiş bir asker olarak emri altındaki orduyu besleyebilmek için sağlıklı besin kaynaklarının teminine yöneldi. Gürcistan arazisinin tarım organizasyonu Rus ordusunu beslemeye yeterli değildi. Moskova ile

23

BOA HH, 36986 Sultan II. Mahmut İran'dan gelen bu mektubun altına "Manzurum olmuştur. Hazz eyledim. Erzurum valisi hareketi için istical emri gitsin, tedat eylediği mevaddı dahi iktizasına göre tanzime bakılsın pek de nafile lakırdılara benzemez." 24

Kafkasyada büyük mücadele için bkz, Sadık Müfit Bilge, "Osmanlı Çağında Kafkasya, 1454-1829", Tarih Toplum Ekonomi, İstanbul, 2015; Mustafa Aydın, Üç Büyük Gücün Çatışma Alanı Kafkaslar, İstanbul 2008.

25

BOA HH., nr., 36669.

BOA HH. nr., 22; Ahmed Cevdet Paşa, age, V, s. 2451.

${ }^{27}$ BOA HH.,nr., 36857-A

${ }^{28}$ Hasanbala Sadıkov, Rusya-Türkiye Münasebetlerinde Cenubi Kafkas Problemi, Bakü 1991 , s. 87.

${ }^{29}$ Süleymanov, a.g.e., s. 430.

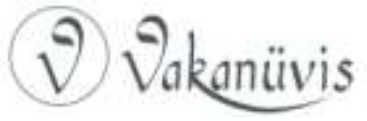


aralarındaki mesafe uzak olunca askeri beslemekte zaman zaman sıkıntı çekiliyordu. Hanlıklar ile zaman zaman erzak alabilmek için ilişkiye giren general bölgedeki gelişmeleri de bu yolla öğrenebiliyordu. Rusyaya karşı oluşmaya başlayan ittifakın neticesini gören general daha fazla beklemeden ani baskınlarla önce Hüseyin Han'ı bozguna uğrattı ve Revan'a çekilmeye mecbur etti. Sonra da Osmanlı -Kaçar müttefik ordusunu da yenerek kendileri açısından çok büyük bir tehlike doğurabilecek bu ittifakı önlemiş oldular 30 .

Veliaht Abbas Mirza Kaçar, Osmanlı orduları ile birlikte Ruslara taarruz etmek niyetiyle Tebriz 'den Revan'a hareket etmişse de Osmanlı - Kaçar işbirliği temin olunamadığından bu seferden bir netice elde edilememiştir. Fakat bu başlangıç iki ülke arasında elçilerin gidip gelmesine vesile oldu. Bu temaslara paralel olarak Osmanlı Devleti şark seraskerliğini güçlendirirken Kafkasya ve Dağıstan'daki Müslümanları Rusya'ya karşı ayaklanmaya çağırıyordu 31 . Revan Hanlığı tarafından şiddetle desteklenen bu gayretler ise Rusya tarafından ise yakından izleniyordu.

Ruslar, casusları vasıtasıyla gelişmeleri takip ediyor, her fırsatta iki devleti birbirine düşürüp ittifakı bozmaya çalışıyordu ${ }^{32}$. Abbas Mirza güçlü bir ordu hazırladı ${ }^{33}$. Osmanlı Devleti ise Şark serdarlığına yeni bir düzen vermek için Emirülhac İbrahim Paşayı yeteri kadar başarı sağlayamadığından azlederek Tokat'a gönderdi. Yerine Veyiszade Emin paşa şark seraskeri ve Erzurum valiliğine tayin edilerek civar vilayetlerin askerlerini de Emin Paşanın emrine verildi ${ }^{34}$. Emin Paşa derhal sefer hazırlıklarına başlayarak yirmi dört bin kişilik bir orduyu

30 Ahmed Cevdet Paşa, a.g.e., V, 2397; Sadıkov, a.g.e., s. 87.

31 A. Arslan, "Rusya'nın Kırım ve Gürcistan'ı İlhakından Sonra Osmanlı Devletinin Çerkez Kabileleri ile Münasebetleri", Kafkas Araştırmaları, İstanbul 1987, I, 47; Sema Işıktan, 1783-1829 Osmanlı Dağıstan Münasebetleri, İstanbul 1987, s. 85. (basılmamış yüksek lisans tezi).

32 Avriyanof, XIX asırda Türkiye Rusya ve Iran Muharebeleri, İstanbul 1926, s.14-16.

Abbas Mirza Hakkında ilk araştırma için bkz., Emine Pakrevan, Abbas Mirze ve Azerbaycan, Bakü, 2007

${ }^{34}$ Ahmed Cevdet Paşa, a.g.e., V, 2400. 
harekete geçirecek konuma getirdi35. Gerekli temaslar sağlandıktan sonra iki ordu Gürcistan üzerine yürüyerek Kafkaslara yayılmaya çalışan Rus tehlikesini bertaraf edeceklerdi. Bu önemli savaşı ortak bir harekat dahilinde yürütebilmek için baştan beri bu ittifakı hazırlayan Revan Hanı Hüseyin Han ile Şark seraskeri Emin Paşa aralarında görüşmeye karar verdiler 36 . Arpaçay nehrinin sağ tarafında bulunan Magazberd kalesinde 30 Ağustos 1811'de gerçekleştirilmesi planlanan savaşın tüm teferruatı görüşüldü. Bu görüşmeye göre Osmanlı ana ordusu Tuna hattında Ruslara cephe açacak, Kafkasya'daki savaşın askeri yükünü İran karşılayacaktır. Karabağ ve Pembek'te toplanacak olan İran askerleri, Revan Hanlığına göndereceği on bin kişilik kuvvet ile Emin Paşanın yirmi dört bin kişilik ordusu birleşecekti. Böylece ordunun sayısı yüz bin kişiyi bulacaktı ${ }^{37}$. Bu rakamlara karşılık Kafkasya'da altmış dört topa sahip Rus askerinin sayısı on yedi bin civarındaydı 38 .

\section{Rusların İttifak Teşebbüsünü Önleme Çalışması: Emin Paşaya Düzenlenen Suikast}

Kafkasya'daki yayılmaları karşısında ciddi bir ittifakın ortaya çıkması durumu Rusları telaşlandırmıştı. Başından beri bu görüşmeleri takip eden Ruslar durumun nazikliğini ve yakın gelecekte nelerin olabileceği gerçeğini kavramışlardı. Bu ezici çoğunluk karşısında her ne pahasına olursa olsun birleşmeyi engellemeye çalışan Rus generali Tomorsov emeline ulaşacaktır.

Ruslara karşı gerçekleşen bu ittifakın en önemli ismi Erzurum Paşası Emin Paşa idi. Ruslar gelişmeleri yakından takip ederken bir savaşa

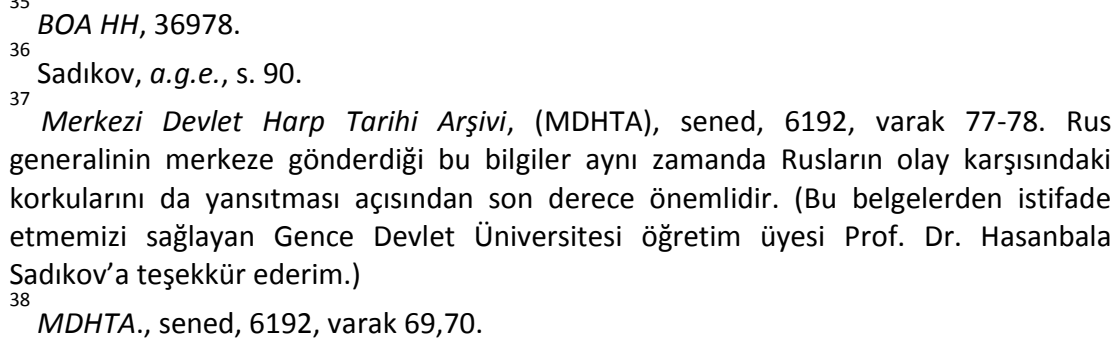
generalinin merkeze gönderdiği bu bilgiler aynı zamanda Rusların olay karşısındaki korkularını da yansıtması açısından son derece önemlidir. (Bu belgelerden istifade etmemizi sağlayan Gence Devlet Üniversitesi öğretim üyesi Prof. Dr. Hasanbala Sadıkov'a teşekkür ederim.) MDHTA., sened, 6192, varak 69,70.

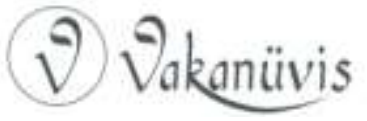


girişmenin Kafkasya'dan atılabilecekleri anlamına geleceğini bildiklerinden acil önlemler alınması konuşuldu. Bir cephe savaşından önce Kafkaslarda casusluk hareketleri ile sonuç alınma yöntemi denenecekti ${ }^{39}$. 1801 yılında ilk Tiflis'e geldikleri günlerde Ruslar bölgede keşfettikleri Kürtler üzerinde çalışmaya başlamışlar, Osmanlı İran arazisinde sürekli hareket halinde olan dolayısıyla da gayrı memnun bir kitleye dönüşen bu topluluklar Rusların dikkatini çekmişti. Rus askeri istihbarat birimleri şu an bir cephe savaşı yapmanın sakıncaları ciddi boyutta sıkıntı çıkaracaktı. Rusya'ya karşı kurulan bu ittifakı dağıtmak için savaş kaçınılmazdı ama şu an Rus orduları bu savaşı göze alamıyordu. Cephe savaşı Rusyanın Kafkaslardan silinmesi demekti. Zira asker sayısı az ve en önemlisi hala yiyecek sıkıntısı çözülememişti. Devreye giren Rus istihbarat birimleri yeni keşfettikleri Kürt aşiretlerini harekete geçirmek istiyorlardı. Aşiretlerin birine mensup bir Kürt fedai görevlendirildi ve bu fedai tarafından Emin Paşa ağır bir şekilde yaralandı (1 Eylül 1811) 40 . Saldırganın kimliği ve bu tür bir davranışa niçin tevessül ettiği konusu önemlidir. 41 Meydana gelen olay karşısında Osmanlılar paniğe kapılarak Emin Paşa'yı hızla Magazberd'den Kars'a naklettiler. Doğu vilayetlerindeki Paşaların kendi arlarındaki çekişme üzerine bina edilmeye çalışılan bu ittifak bir suikast ile dağılması belki Osmanlı ve Kaçar hanedanına Kafkasya'yı kaybetmesine sebep olmuştu ama üzerinde düşünülmesi gereken Rus tehlikesinin yeteri kadar anlaşılamamış olmasıdır. Bütün mesaisini bu

${ }^{39}$ Kafkasya'daki nefes kesen casusluk faaliyetleri için bkz. Ahmet Yüksel, Rusların Kafkasya'yı İstilası ve Osmanlı İstihbarat Ağı, İstanbul 2014

40

Mustafa Budak, "Osmanlı-Rus ilişkilerinde Kafkasya”, Avrasya Etütleri, Ankara 1995, kış IV, s. 113; Murat Özsoy, Rus iran Münasebetleri, Van 1998, s. 14 (yayınlanmamış mezuniyet tezi); Ömer Halis, "Rus-íran Münasebetleri", Mecmuayı Askeriye istanbul 1341, sayı 58, s. 195; Coşkun Tüfekçi, Osmanlı Iran iliş̧kileri (1795-1896) (Casusluk Faaliyetleri Çerçevesinde), yayınlanmamış yüksek lisans tezi, Kırıkkale. 41

Kürt meselesini Rusların bu tarihte görmüş olması ve uzun vadeli bir çalışmaya başlamasını Türk ve İran coğrafyası tarihçilerinin dikkatle incelemesi gereken bir konudur.

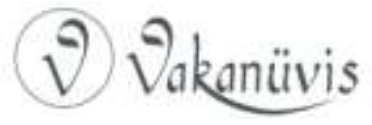


ittifak için harcayan ve gelen tehlikeyi en iyi gören Revan Hanı Hüseyin Han ise çaresizlik içinde Revan'a çekildi ${ }^{42}$.

Rusların irtibat kurup Osmanlı İran ve Revan hanlığına karşı kullandığı bölgedeki aşiretlerle özellikle Kürt aşiretleriyle yeteri kadar ilgilenilememesinin neticesinde Ruslar bölgede etkili bir unsuru yanlarına çekmiş oluyorlardı 43 . Hatta bu aşiretleri zaman zaman iki devlet arasında savaşa sebebiyet verebilecek derecede kışkırtarak Osmanlılar ile İranlılar arasındaki barışı bozmuşlardır. Böylelikle Rusya ileride Osmanlı'ya karşı kullanabileceği Gürcistan'ın yanında Ermeniler ve Kürtlerin oluşturacağı iki yeni siyasi oluşumun kendisine sağlayacağı imkânları en iyi şekilde idrak etmiş oluyordu. Daha 1811 yılında Rusların uygulamaya çalıştıkları bu düşünce bir yandan bölgedeki Osmanlı-iran varlığını tamamen bertaraf ederken öte yandan Rusya'nın kalıcı bir şekilde bölgeye yerleşmesinin aracı olacaktı. ${ }^{44}$ Maalesef Osmanlılar ve İran'daki yöneticilerin Rusların bu niyetini zamanında anlayıp gerekli tedbirleri alamamışlardır.

Ruslarla Osmanlılar arasındaki savaş sadece Doğu Cephesi'nde devam etmiyordu. Aynı zamanda Batı'da da; Rumeli cephesinde Rus taarruzları hat safhaya ulaşmıştı. Doğu Cephesinde Emin Paşa'ya yapılan suikast etkisini göstermiş ve Osmanlı devleti daha fazla kayba uğramamak için 1812'de Bükreş Anlaşmasını imzalamak zorunda kalmıştır. Bu anlaşma gereği Ruslar işgal ettikleri yerlerden çekilecekti dolayısıyla Revan Hanlığı ve İran baş başa kaldılar45. Ruslar İran ve

42

MDHTA., sened, 2889, varak 73-74; BO. HH., nr. 37177; Baddeley, a.g.e., s. 101; Sadıkov, a.g.e., s. 93; Kalantari Yahya, Feth-Ali Şah Zamanında Osmanlı Iran Münasebetleri, İstanbul 1976 (i..Ü. Ed. Fak Yayınlanmamış Doktora Tezi)s. 80-84; Hasan Oktay, "Revan Hanlığı ve Hanları", Tarihte Türkler ve Ermeniler, IV, s. 166, TTK yayınları Ankara 2014; Hasan Oktay, "Osmanlı -Rus-İran Rekabetinde Revan Hanlığı ve Hanları", VIII. Milletlerarası Türkoloji Kongresi, IV, s. 978, İstanbul 2014.

43

Minorsky, "Kürtler", i.A., XI; N. Sevgen, "Kürtler", BTTD., I-III., İstanbul. 44

W.E.D. Allen, Paul Muratoff, Kafkas Harekatı 1828-1921 Türk Kafkas Sınırındaki Harplerin Tarihi, Ankara 1966, s. 31. Türkler Kürtlerle olan münasebetlerinde daha az başarılıydılar. 45

i. H. Danişmend, İzahlı Osmanlı Tarihi Kronolojisi, İstanbul 1965, IV, 100; Enver Ziya Karal, Osmanlı Tarihi, V, s, 100, TTK yayınları Ankara 1983; İorga, Osmanlı Tarihi, s.325; Ahmed Cevdet Paşa, a.g.e., V, s. 2453; Bükreş anlaşması sonucu Ruslar Kafkas dağların

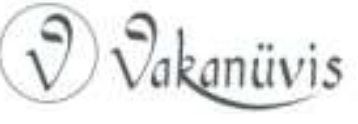


Osmanlıya karşı Gürcistan, Ermenistan devletinden sonra Kürdistan diye paravan bir yapı oluşturup bu iki devletten gelecek tehlikeyi tamamen bertaraf etmek istiyordu 46 . Safevi devleti kuruluşuyla başlayan ve daha sonra kendisini iyice hissettiren Osmanlı İran çekişmesi ilk defa bir dostluk ve işbirliği havasına bürünmüş, askeri manada bir ittifak oluşmuştu. Bu ittifakın yakın ve uzak hedefleri göz önünde bulundurularak değerlendirilseydi belki de bu gün Ruslar bu kadar yayılamayacaktı. Emin Paşaya düzenlenen suikast tabii ki tek başına bölgedeki hareketliliği ve dönüşümü tetiklemedi. Bugün bakıldığında belki anlamsız gelebilecek Osmanlı Türkü ile İran coğrafyasında yaşayan Türk'ün mezhep savaşı içine düşmeleri ki Kerbela vakası olduğu tarihte Türkler daha Müslüman bile olmamışken Kerbela'nın intikamını kendi aralarında alma arayışı en fazla Türkleri etkilemiştir. Ayrıca bu rekabet hem Osmanlı ve hem de İran Türklerini sınırlarda yaşayan aşiretlere karşı daha mutedil davranmalarına sebep olmuştur. Aşiretleri kendi yanlarında tutabilmek için uyguladıkları sistem çökmüş, Ruslar ise bölgeye geldiklerinde bu durumu keşfetmişler ve bu aşiretler üzerinden bölgede yeni sosyal ve siyasal dinamikleri harekete geçirmişlerdir. 47

\section{Kaynakça}

Arşiv vesikaları

BOA, HH., nr.,36676

B.O.A., Cevdet Hariciye, (C.H), nr. 2623.

BOA HH, 36696

BOA HH, 36986

kuzeyindeki nehir kıyıları boyunca yerleşme fırsatı elde ettiler. Daryal ve Mamison geçitlerini ele geçiren Ruslar artık sistemli bir şekilde Güney Kafkasyaya yayılmanın önünü açmış oldular. Buna bir de savaş sonrası yayılan veba salgını 1811-1813 Rusya'nın işine çok yaramış oldu. Müfit Sadık Bilge, age, s. 354-355. 46

Avriyanof, a.g.e., s. 17.

${ }^{47}$ Rusların Kürt aşiretlerini keşfetmeleri ve onlar üzerinden Osmanlı İmparatorluğu ile Türkistan Türkleri arasındaki coğrafi irtibatın kesilmesi için yürüttüğü siyaset için bknz, M. S. Lazarev, Emperyalizm ve Kürt Sorunu, Özge Yayınları Ankara, baskı tarihi bulunmamaktadır.

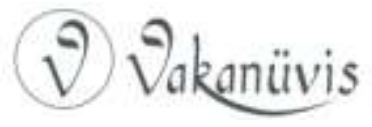


BOA HH, 36986

BOA HH., nr., 36669.

BOA HH. nr., 22

BOA HH.,nr., 36857-A

BO. HH. nr. 37177

Merkezi Devlet Harp Tarihi Arşivi, (MDHTA), sened,6192, varak 77-78. MDHTA., sened, 6192, varak 69,70.

MDHTA., sened, 2889, varak 73-74

\section{Araştırma Eserleri}

Abdullaev, G.B, Azerbaidzhana $v$ XVIII Veke I Vzaimaotnoshcnira $s$ Roussie, Bakü 1965.

Acar, Sekan, "Kazan Hanlığı", Avrasyanın Sekiz Asrı Çengizoğulları, İstanbul 2016.

Ahmed Cevdet Paşa, Tarihi Cevdet, V, 2400.

Armani, Henry J, The Russuan Annexation of Imeratıa (1800-1815), Washington 1970.

Arslan, Ali, "Rusyanın Kırım ve Gürcistanı Illhakından Sonra Osmanlı Devletinin Çerkez Kabileleri ile Münasebetleri", Kafkas Araştırmaları, İstanbul 1987.

Avriyanof, XIX asırda Türkiye Rusya ve Iran Muharebeleri, İstanbul 1926.

Aydın , Mustafa, Üç Büyük Gücün Çatışma Alanı Kafkaslar, İstanbul 2008.

Azerbaycan Tarihi, Azerbaycan ilimler Akademisi Yayınları, Bakü 1964.

Azerbaycan Tarihi, Azerbaycan ilimler Akademisi Yayınları, Bakü 1993.

Azerbaycan Tarihi, En Eski Devirlerden XX. Asrın Evveline Kadar, Azerbaycan İlimler Akademisi Yayınları, Bakü 1992.

Baddeley, J. F., Rusların Kafkasyayı İstilası ve Şeyh Şamil, İstanbul 1989.

Bilge, Sadık Müfit, "Osmanlı Çağında Kafkasya, 1454-1829", Tarih Toplum Ekonomi, İstanbul, 2015.

"I. Petro'nun 1725 yılında yazdığı vasiyetnamesi", Türk Kültürü Dergisi, Ankara 1990, XXVIII/323

Bakıhanov, Gülistan-ı Irem, Bakü 1941.

Budak, Mustafa, "Osmanlı-Rus ilişkilerinde Kafkasya", Avrasya Etütleri, Ankara 1995, kış IV.

Danişmend, I. H., Izahlı Osmanlı Tarihi Kronolojisi, İstanbul 1965, IV, 100.

Delili , Hasan Ali, XVIII. Asrın Ikinci Yarısında Cenubi Azerbaycan Hanlıkları, Bakü 1979.

Işıktan, Sema, 1783-1829 Osmanlı Dağıstan Münasebetleri, İstanbul 1987 (basılmamış yüksek lisans tezi).

İorga, N, Osmanlı Tarihi, İstanbul 1989.

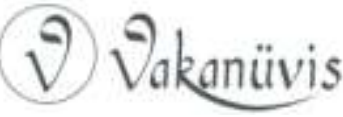


Kafalı, Mustafa, Altın Orda Hanlıklarının Kuruluş ve Yükseliş Devirleri, İstanbul 1980.

Kalantari Yahya, Feth-Ali Şah Zamanında Osmanlı Iran Münasebetleri, İstanbul 1976 (i.ü. Ed. Fak Yayınlanmamış Doktora Tezi).

Kamalov , İlyas, Altınorda ve Rusya, İstanbul 2009.

Karal, Enver Ziya, Osmanlı Tarihi, V, s, 100, TTK yayınları Ankara 1983.

Köse, Ensar, XVIII. Yüzyılın Başlarında Kafkaslarda Nüfuz Mücadelesi, yayınlanmamış yüksek lisans tezi, İstanbul 1996.

Köse , Osman, 1774 Küçük Kaynarca Anlaşması, TTK Ankara 2006.

Kuzgun , Şaban, Hazar ve Karay Türkleri, Ankara 1993.

Kurat, Akdes Nimet, Türkiye ve Rusya, Ankara 1990.

Kurat, Akdes Nimet, Türkiye ve Idil Boyu, Ankara 2011.

Lazarev, M. S. , Emperyalizm ve Kürt sorunu, Özge Yayınları Ankara.

Süleymanov, Mehman, Gülistan Müqavilesi, I-II, Bakü 2014.

Minorsky, "Kürtler", i.A., XI.

Nusel, Emre, 1787-1792 Osmanlı-Rus Savaşında Kafkas Hanlıklarının Faaliyetleri, yayınlanmamış yüksek lisans tezi, Edirne 2015.

Oktay, Hasan, Revan Hanlığı, Malatya 1997, (yayınlanmamış doktora tezi).

Oktay, Hasan, "Revan Hanlığı ve Hanları", Tarihte Türkler ve Ermeniler, IV, s. 166, TTK yayınları Ankara 2014.

Oktay, Hasan, "Osmanlı -Rus-ïran Rekabetinde Revan Hanlığı ve Hanları", VIII. Milletlerarası Türkoloji Kongresi, IV, s. 978, İstanbul 2014.

Ömer Halis, "Rus-İran Münasebetleri”, Mecmuayı Askeriye, İstanbul 1341.

Özcan , Altay Tayfun, Moğol Rus iliş̧kileri, Ankara 2017.

Özsoy, Murat, Rus iran Münasebetleri, Van 1998 (yayınlanmamış mezuniyet tezi).

Pakrevan , Emine, Abbas Mirze ve Azerbaycan, Bakü, 2007.

Sadıkov, Hasanbala, Rusya-Türkiye Münasebetlerinde Cenubi Kafkas Problemi, Bakü 1991.

Sevgen, Nazmi , "Kürtler", BTTD., I-III., İstanbul.

Tüfekçi , Coşkun, Osmanlı Iran Iliş̧kileri (1795-1896) (Casusluk Faaliyetleri Çerçevesinde), yayınlanmamış yüksek lisans tezi, Kırıkkale.

Vernadsky, George, Moğollar ve Ruslar, İstanbul 2007.

Allen, W.E.D., Paul Muratoff, Kafkas Harekatı 1828-1921 Türk Kafkas Sınırındaki Harplerin Tarihi, Ankara 1966.

Yakubovsky, Altınordu ve Çöküşü, Ankara 1976.

Yazıcı, Orhan, Afganistan'da Ingiliz-Rus Nüfuz Mücadelesi, Malatya 1996, basılmamış yüksek lisans tezi.

Yüksel, Ahmet, Rusların Kafkasyayı İstilası ve Osmanlı İstihbarat Ağı, İstanbul 2014.

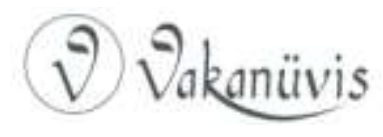

